Article

\title{
Low Effectiveness of the Introduction of pmaxGFP into Primary Human Coronary Endothelial Cells Using Cell-Penetrating Peptides and Nuclear-Localization Sequences in Non-Covalent Interactions
}

\author{
Wioletta Zielińska ${ }^{+}$(D), Maciej Gagat*,+(D), Klaudia Mikołajczyk, Marta Hałas-Wiśniewska (D) and Alina Grzanka \\ Department of Histology and Embryology, Faculty of Medicine, Collegium Medicum in Bydgoszcz, \\ Nicolaus Copernicus University in Toruń, 85-092 Bydgoszcz, Poland; w.zielinska@cm.umk.pl (W.Z.); \\ klaudia.mikolajczyk@cm.umk.pl (K.M.); mhalas@cm.umk.pl (M.H.-W.); agrzanka@cm.umk.pl (A.G.) \\ * Correspondence: mgagat@cm.umk.pl; Tel.: +48-52-585-37-25 \\ + These authors contributed equally to the work.
}

check for updates

Citation: Zielińska, W.; Gagat, M.; Mikołajczyk, K.; Hałas-Wiśniewska, M.; Grzanka, A. Low Effectiveness of the Introduction of pmaxGFP into Primary Human Coronary Endothelial Cells Using Cell-Penetrating Peptides and Nuclear-Localization Sequences in Non-Covalent Interactions. Appl. Sci. 2021, 11, 1997. https://doi.org/ 10.3390/app11051997

Received: 13 January 2021

Accepted: 17 February 2021

Published: 24 February 2021

Publisher's Note: MDPI stays neutral with regard to jurisdictional claims in published maps and institutional affiliations.

Copyright: (c) 2021 by the authors. Licensee MDPI, Basel, Switzerland. This article is an open access article distributed under the terms and conditions of the Creative Commons Attribution (CC BY) license (https:// creativecommons.org/licenses/by/ $4.0 /)$.

\begin{abstract}
Cell-penetrating peptides (CPPs), due to their effectiveness and low cytotoxicity, are of increasing interest in the context of the transport of macromolecules to the cells. The simplest and safest method seems to be the non-covalent binding of CPP and cargo molecules. However, it requires the optimization of the reaction conditions. The study aimed to determine the effectiveness and cytotoxicity of the Pep-1, KALA, and TAT proteins as well as the NLS [47-55] and NLS [47-56] sequences derived from the Simian Vacuolating 40 (SV40) T-antigen in the context of the transport of the pmaxGFP plasmid to primary human coronary artery endothelial cells. The results are presented in the form of extensive photographic documentation, which shows significant differences in the efficiency of the transfection process between electroporation and the use of CPPs. The study presents negative results in which, despite the manipulation of various parameters (incubation time, incubation temperature, culture time, charge ratio, plasmid concentration), results similar to electroporation were not obtained.
\end{abstract}

Keywords: cell-penetrating peptides; primary human coronary artery endothelial cells; TAT; KALA; Pep-1

\section{Introduction}

Cell-penetrating peptides (CPPs), also referred to as protein transduction domains (PTDs) or Trojan peptides, form a structurally diverse group of molecules with varied physicochemical properties. However, they usually have at least two features in common. Firstly, they can penetrate the cell membrane barrier even after binding with macromolecules. Secondly, they are mostly short peptides with a length of up to 30 amino acids [1]. Moreover, in vitro and in vivo studies have indicated their low cytotoxicity and immunogenicity together with high efficiency.

CPPs may enter the cell due to several mechanisms, including clathrin-dependent and independent endocytosis and direct translocation. Additionally, this characteristic is not affected by the attachment of varied cargo molecules to the CPP [1].

Two main approaches are currently applied for combining transported molecules with CPPs. The first is the introduction of a covalent bond, while the second is based on the creation of non-covalent interactions. Although covalent bonding is commonly used, it has several disadvantages. An example is the probability of undesirable changes in the attached molecule during a chemical reaction [2]. Moreover, it cannot be used for the transport of plasmids. To overcome these problems, non-covalent bonds can be applied. In such a case, the cargo and CPP are combined with electrostatic and hydrophobic interactions. This limits the possibility of changes in biological activity resulting from binding. Furthermore, 
it enables the transport of plasmids. Another advantage is the simplicity of the method since it only requires incubation of the compounds. Moreover, this strategy is similar, in terms of effectiveness and safety, to the introduction of covalent bonds [3,4].

The effectiveness of the non-covalent approach strongly depends on the charge ratio (CR), which is the ratio of the number of moles of positively charged amino acid groups in the CPP to the number of moles of negatively charged groups in the binding molecule [5]. Too high of a CR results in the formation of large complexes of molecules with low cellular penetration capacity, while too low is not effective due to insufficient internalization.

The study aimed to assess the usefulness of selected CPPs (TAT, Pep-1, KALA) and nuclear localization sequences (NLS [47-55] and NLS [47-56]) for introducing pmaxGFP plasmids to the human primary coronary artery endothelial cells. Both the effectiveness and potential cytotoxic effect were assessed. The results are presented in the form of extensive photographic documentation, which shows significant differences in the efficiency of the transfection process between electroporation and the use of CPPs.

\section{Materials and Methods}

\subsection{Cell Culture}

Commercially available human primary coronary artery endothelial cells (pHCAEC; ATCC, Manassas, VA, USA) were used in the study. The cells were obtained from a 23-yearold Caucasian male. The donor died as a result of a blunt head injury. Cells after the third passage positively passed virological tests and then were frozen and transported.

The pHCAEC cell line was cultured according to the manufacturer's instructions in Vascular Cell Basal Medium (ATCC) in combination with Endothelial Cell Growth KitVEGF (ATCC). The culture was carried out under standard conditions $\left(37^{\circ} \mathrm{C}, 5 \% \mathrm{CO}_{2}\right)$ in the presence of antibiotics-penicillin $(10 \mu \mathrm{g} / \mathrm{mL})$, streptomycin $(10 \mu \mathrm{g} / \mathrm{mL})$ and amphotericin B $(25 \mu \mathrm{g} / \mathrm{mL}$; ATCC).

To assess the efficiency of transport, endothelial cells were incubated with electrostatic complexes of CPPs and plasmid pmaxGFP for 24 or $48 \mathrm{~h}$. Control cells were cultured under the same conditions and underwent (I) no incubation with CPPs and plasmid, (II) incubation with the plasmid vector alone.

\subsection{Formation of Electrostatic Interactions between Plasmid and Penetrating Proteins}

The vector used in the study was the pmaxGFP plasmid (Lonza, Basel, Switzerland), which conditions the expression of green fluorescence protein (GFP). Additionally, three types of CPPs-Pep-1 (synthetic CPP with primary amphipathicity resulting from the amino acid sequence itself, not from the folding structure, that comprises a tryptophan-rich hydrophobic domain, a hydrophilic domain derived from an NLS of simian virus 40 (SV40) large T-antigen, and a spacer between them (a cysteamine group of Pep-1 is present at the C-terminus and plays a crucial role in the delivery of cargoes into the cells)), KALA (synthetic, cationic amphipathic CPP, with $\alpha$-helix conformation when the $\mathrm{pH}$ is 7.5; it binds oligonucleotides and disrupts the cell membrane), and HIV transactivator protein (TAT) were applied. Moreover, two different nuclear localization sequences (NLS) were also assessed. These were NLS [47-55] and NLS [47-56] derived from the SV40 T-antigen, which can pass through the pores of the nuclear envelope to the interior of the cell nucleus due to the strong affinity for importin (All from AnaSpec, Fremont, CA, USA).

To determine the effect of incubation conditions on the efficiency of non-covalent bonding between CPPs and pmaxGFP, variable conditions were used in regards to: (I) the type of CPP/NLS (TAT, KALA, Pep-1, NLS [47-55] and NLS [47-56]), (II) the charge ratio $(1: 1,1: 2,1: 4,1: 8,1: 16)$, (III) the amount of plasmid (1 or $2 \mu \mathrm{g})$, (IV) the temperature (21 or $\left.37^{\circ} \mathrm{C}\right)$, and $(\mathrm{V})$ the incubation time (15 or $\left.30 \mathrm{~min}\right)$. The influence of the length of culture in the presence of complexes ( 24 or $48 \mathrm{~h}$ ) was also evaluated. The applied conditions are summarized in Table 1. 
Table 1. Conditions of CPP-cargo complexes preparation.

\begin{tabular}{|c|c|c|c|c|c|c|c|c|c|}
\hline \multirow[t]{2}{*}{$\begin{array}{l}\text { Type of } \\
\text { CPP/NLS }\end{array}$} & \multirow{2}{*}{$\begin{array}{c}\mathrm{CR}^{\mathbf{1}} \\
1: 1\end{array}$} & \multicolumn{2}{|c|}{$\begin{array}{c}\text { Amount of } \\
\text { Plasmid }[\mu \mathrm{g}]\end{array}$} & \multicolumn{2}{|c|}{$\begin{array}{c}\text { Time of } \\
\text { Incubation [min] }\end{array}$} & \multicolumn{2}{|c|}{$\begin{array}{c}\text { Time of } \\
\text { Culture [h] }\end{array}$} & \multicolumn{2}{|c|}{$\begin{array}{l}\text { Temperature of } \\
\text { Incubation }\left[{ }^{\circ} \mathrm{C}\right]\end{array}$} \\
\hline & & 1 & 2 & 15 & 30 & 24 & 48 & 21 & 37 \\
\hline \multirow{6}{*}{ TAT } & $1: 2$ & & 2 & 15 & 30 & 24 & 48 & 21 & 21 \\
\hline & $1: 4$ & 1 & 2 & 15 & 24 & 24 & 48 & 21 & 37 \\
\hline & $1: 8$ & 1 & 2 & 15 & 30 & 24 & 48 & 21 & 37 \\
\hline & $1: 16$ & & 1 & 15 & 30 & 24 & 48 & 21 & 37 \\
\hline & 1:1 & 1 & 2 & 15 & 30 & 24 & 48 & 21 & 37 \\
\hline & $1: 2$ & & 2 & 15 & 30 & 24 & 48 & 21 & 37 \\
\hline \multirow[t]{5}{*}{ Pep-1 } & $1: 4$ & 1 & 2 & 15 & 30 & 24 & 48 & 21 & 21 \\
\hline & $1: 8$ & 1 & 2 & 15 & 30 & 24 & 48 & 21 & 37 \\
\hline & $1: 16$ & & 1 & 15 & 30 & 24 & 48 & 21 & 37 \\
\hline & 1:1 & 1 & 2 & 15 & 30 & 24 & 48 & 21 & 21 \\
\hline & $1: 2$ & & 2 & 15 & 30 & 24 & 48 & 21 & 37 \\
\hline \multirow[t]{4}{*}{ KALA } & $1: 4$ & 1 & 2 & 15 & 30 & 24 & 48 & 21 & 37 \\
\hline & 1:8 & 1 & 2 & 15 & 30 & 24 & 48 & 21 & 21 \\
\hline & $1: 16$ & & 1 & 15 & 30 & 24 & 48 & 21 & 37 \\
\hline & 1:1 & & 2 & 15 & 30 & 24 & 48 & 21 & 37 \\
\hline \multirow{4}{*}{$\begin{array}{c}\text { NLS } \\
{[47-55]}\end{array}$} & $1: 2$ & & 2 & 15 & 30 & 24 & 48 & 21 & 21 \\
\hline & $1: 4$ & & 2 & 15 & 30 & 24 & 48 & 21 & 37 \\
\hline & $1: 8$ & & 2 & 15 & 30 & 24 & 48 & 21 & 37 \\
\hline & 1:1 & & 2 & 15 & 30 & 24 & 48 & 21 & 21 \\
\hline \multirow{3}{*}{$\begin{array}{c}\text { NLS } \\
{[47-56]}\end{array}$} & $1: 2$ & & 2 & 15 & 30 & 24 & 48 & 21 & 37 \\
\hline & $1: 4$ & & 2 & 15 & 30 & 24 & 48 & 21 & 37 \\
\hline & $1: 8$ & & 2 & 15 & 30 & 24 & 48 & 21 & 37 \\
\hline
\end{tabular}

\subsection{Results Evaluation}

The analysis of the results was made by a visual evaluation of the images obtained using the system for visualization of cells from Zeiss and Zeiss Zen software and cell counting with ImageJ (NIH). The parameters used were defined based on the control cells. The process efficiency was compared to the one received with transfection of pHCAEC using pmaxGFP and electroporation by nucleofection (4D-Nucleofector; Lonza) and P3 Primary Cell 4D-Nucleofector ${ }^{\circledR} \mathrm{X}$ kit (Lonza). Every variant of the experiment was done in at least three independent experiments. Pictures included in the publication show representative views for all of the experiments. Additionally, for greater readability, the results are presented in the form of heatmaps showing the mean and the standard deviations (in parentheses) created with GraphPad Prism (version 7.0 for Mac, GraphPad Software, La Jolla, CA, USA).

\section{Results}

The results were presented in the form of extensive photographic documentation. Cells with the expression of plasmid are characterized by green fluorescence. For control cells, no positive signal was observed (Figure 1). This confirms the assumption that the plasmid alone is not able to penetrate the cell membrane.

Figures 2-22. Variations in the conditions of complex formation and the time of incubation with cells affected the efficiency of the transduction process. For CPP complexes with $1 \mu \mathrm{g}$ plasmid, only single cells expressing GFP were observed either after $24 \mathrm{~h}$ (Figures 2 and 3) or $48 \mathrm{~h}$ culture (Figures 4 and 5). For this reason, further tests were carried out using $2 \mu \mathrm{g}$ of pmaxGFP. In addition, CR 1:16 caused a significant cytotoxic effect. This was especially visible in the case of the KALA protein and contributed to the reduction of CR used in subsequent stages of the study (Figures 2-5). Extending the incubation time of CPPs with the plasmid led to an increase in the number of GFP positive cells (Figures 10-13 and 18-21). In turn, increasing the temperature during complex formation enhanced cytotoxicity, particularly for Pep-1 and TAT (Figures 8, 9, 12, 13, 16, 17, 20 and 21). 
At the same time, no significant influence of temperature on process efficiency was observed. In contrast, extending the culture time in the presence of CPPs and plasmid complexes from 24 to $48 \mathrm{~h}$ led to a significant increase in the number of cells characterized by green fluorescence (Figures 4-7 and 14-21). At low CR and complex formation temperatures of $21^{\circ} \mathrm{C}$, none of the proteins used showed significant cytotoxicity. The optimal CR for the CPPs and plasmid used varied depending on the conditions used. However, regardless of the approach applied, in none of the cases was efficiency even close to that obtained using electroporation by nucleofection (Figure 22).
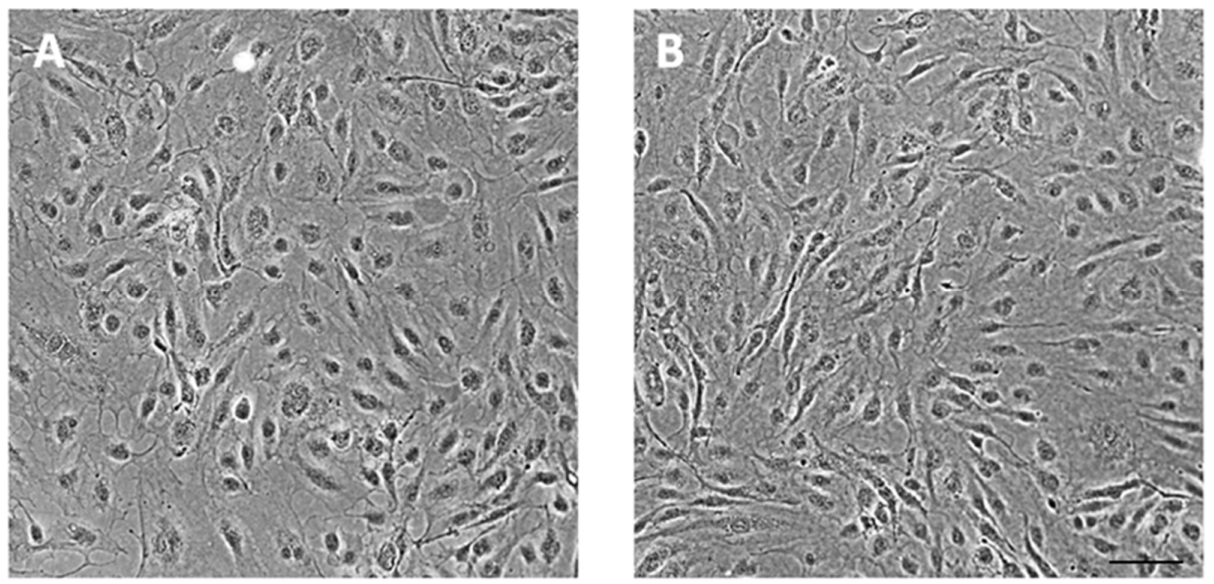

Figure 1. Control cells cultured under standard conditions did not show GFP expression. Control groups were cells cultured in pure medium (A) and in medium supplemented with $1 \mu \mathrm{g}$ of plasmid (B). Bar $=50 \mu \mathrm{m}$.
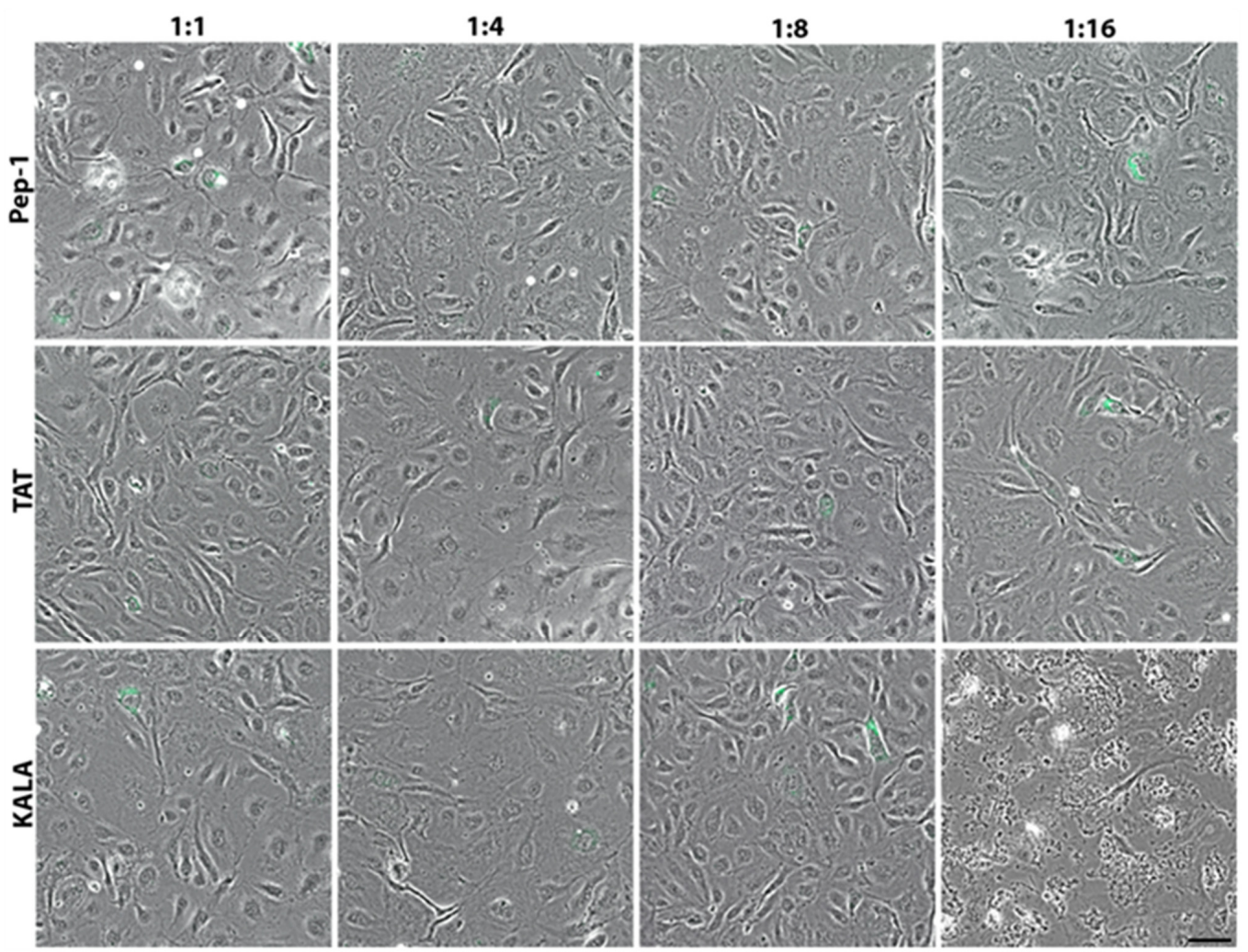

Figure 2. Results of $24 \mathrm{~h}$ culture in the presence of complexes in CRs of 1:1, 1:4, 1:8 and 1:16. The complexes were formed using incubation of $1 \mu \mathrm{g}$ pmaxGFP with chosen CPPs at $21^{\circ} \mathrm{C}$ for $15 \mathrm{~min}$. Bar $=50 \mu \mathrm{m}$. CR, charge ratio. 

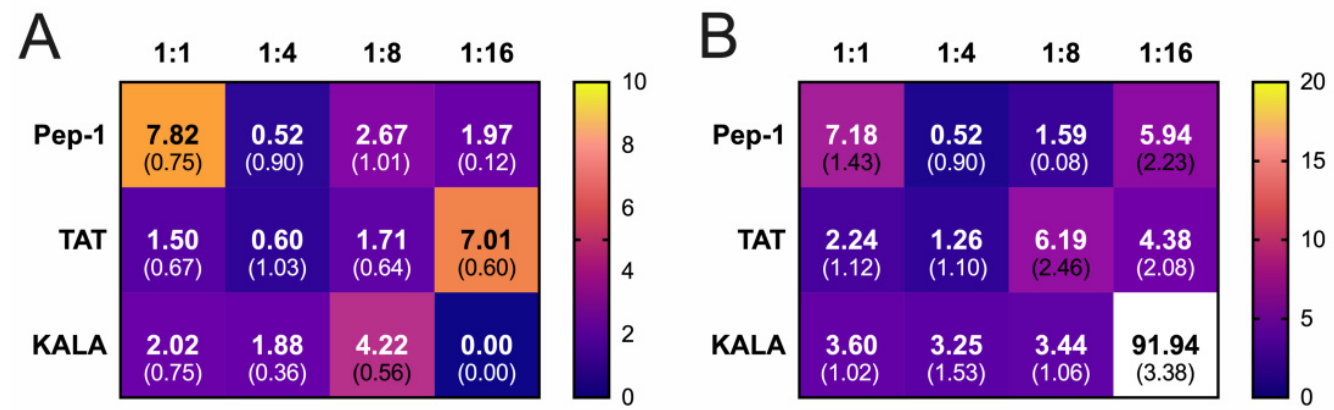

Figure 3. Effect of $24 \mathrm{~h}$ culture in the presence of complexes in CRs of 1:1, 1:4, 1:8 and 1:16. The complexes were formed using incubation of $1 \mu \mathrm{g}$ pmaxGFP with chosen CPPs at $21^{\circ} \mathrm{C}$ for $15 \mathrm{~min}$. CR, charge ratio. (A) Transfection efficiency. (B) Percent of cells with abnormal morphology. Data are presented as means, numbers in parentheses represent standard deviations.

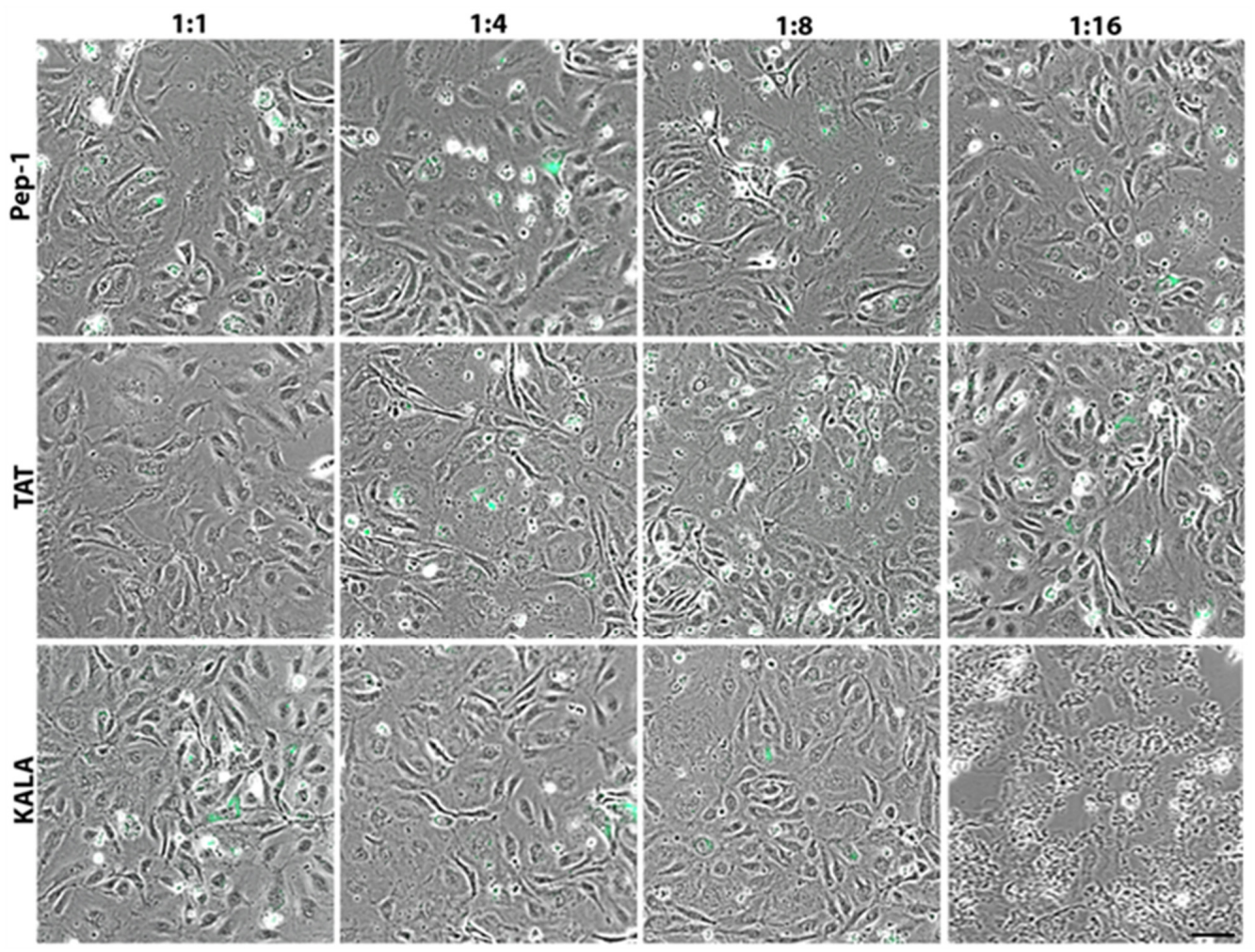

Figure 4. Results of $48 \mathrm{~h}$ culture in the presence of complexes in CRs of 1:1, 1:4, 1:8 and 1:16. The complexes were formed using incubation of $1 \mu \mathrm{g}$ pmaxGFP with chosen CPPs at $21^{\circ} \mathrm{C}$ for $15 \mathrm{~min}$. Bar $=50 \mu \mathrm{m}$. CR, charge ratio.
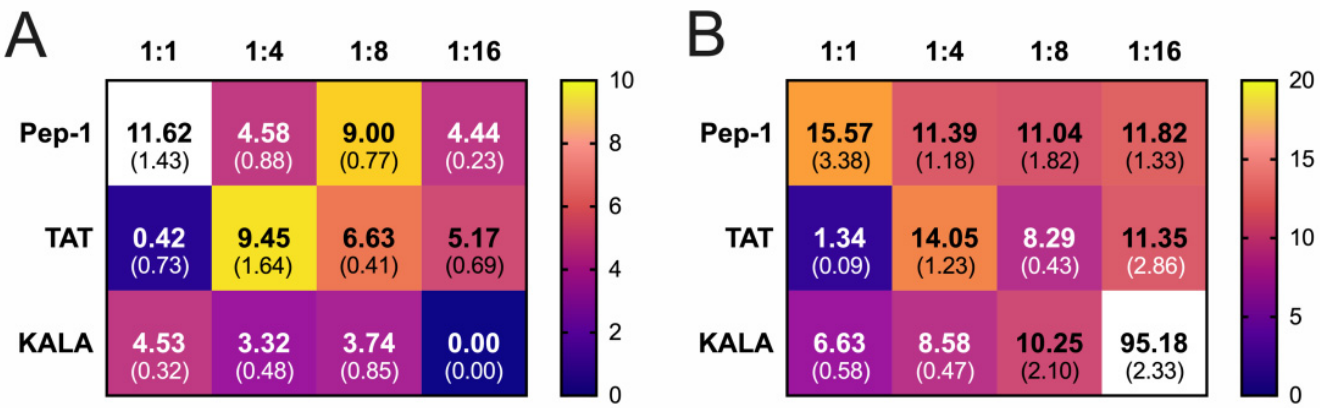

Figure 5. Effect of $48 \mathrm{~h}$ culture in the presence of complexes in CRs of 1:1, 1:4, 1:8 and 1:16. The complexes were formed using incubation of $1 \mu \mathrm{g}$ pmaxGFP with chosen CPPs at $21^{\circ} \mathrm{C}$ for $15 \mathrm{~min}$ CR, charge ratio. (A) Transfection efficiency. (B) Percent of cells with abnormal morphology. Data are presented as means, numbers in parentheses represent standard deviations. 


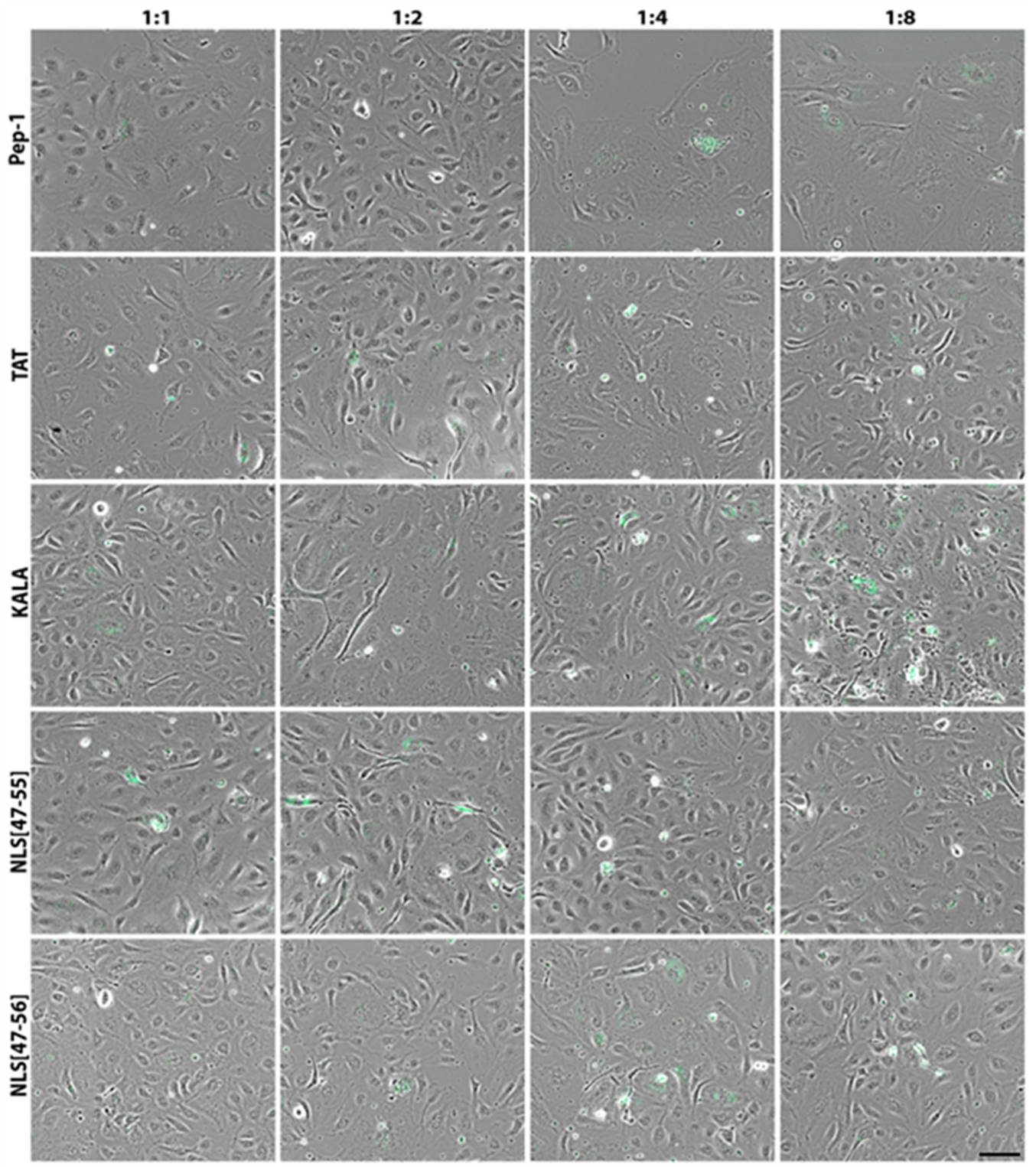

Figure 6. Results of $24 \mathrm{~h}$ culture in the presence of complexes in CRs of 1:1, 1:2, 1:4 and 1:8. The complexes were formed using incubation of $2 \mu \mathrm{g}$ pmaxGFP with chosen CPPs at $21^{\circ} \mathrm{C}$ for $15 \mathrm{~min}$. Bar $=50 \mu \mathrm{m}$. CR, charge ratio.
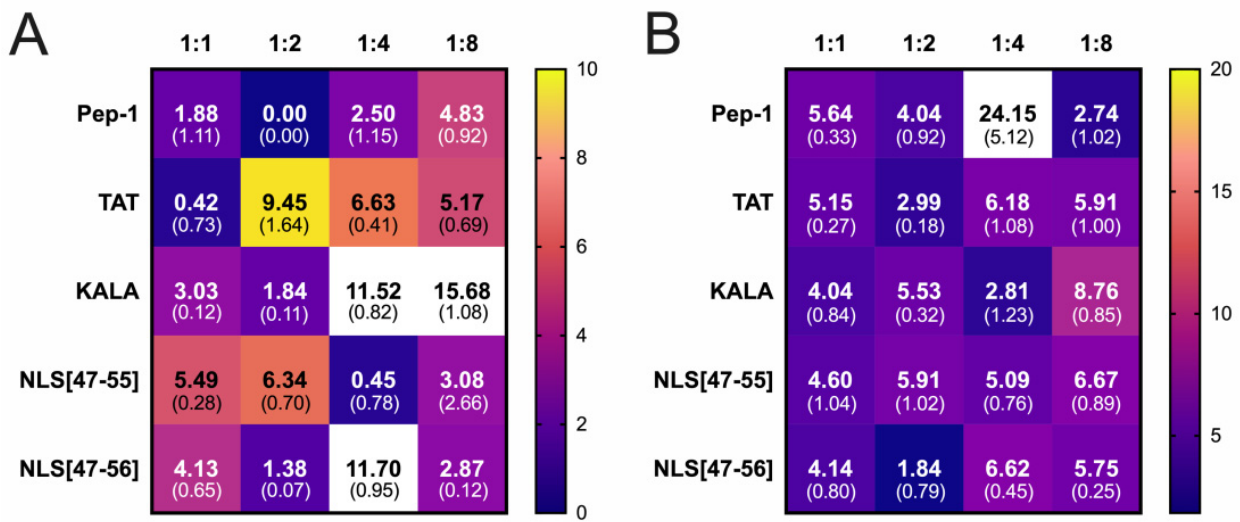

Figure 7. Effect of $24 \mathrm{~h}$ culture in the presence of complexes in CRs of 1:1, 1:2, 1:4 and 1:8. The complexes were formed using incubation of $2 \mu \mathrm{g}$ pmaxGFP with chosen CPPs at $21^{\circ} \mathrm{C}$ for $15 \mathrm{~min}$. CR, charge ratio. (A) Transfection efficiency. (B) Percent of cells with abnormal morphology. Data are presented as means, numbers in parentheses represent standard deviations. 


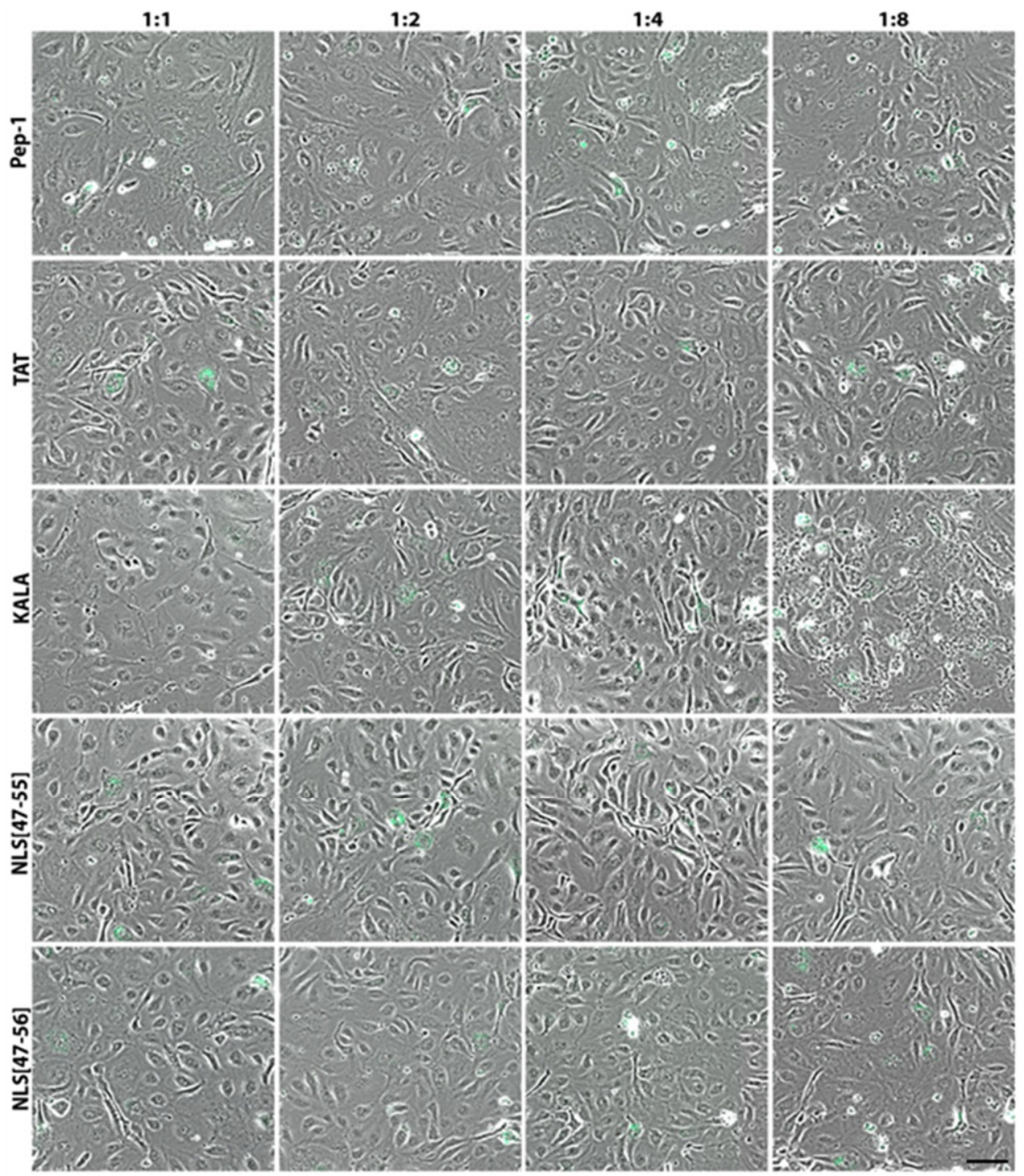

Figure 8. Results of $24 \mathrm{~h}$ culture in the presence of complexes in CRs of 1:1, 1:2, 1:4 and 1:8. The complexes were formed using incubation of $2 \mu \mathrm{g}$ pmaxGFP with chosen CPPs at $37^{\circ} \mathrm{C}$ for $15 \mathrm{~min}$. Bar $=50 \mu \mathrm{m}$. CR, charge ratio.
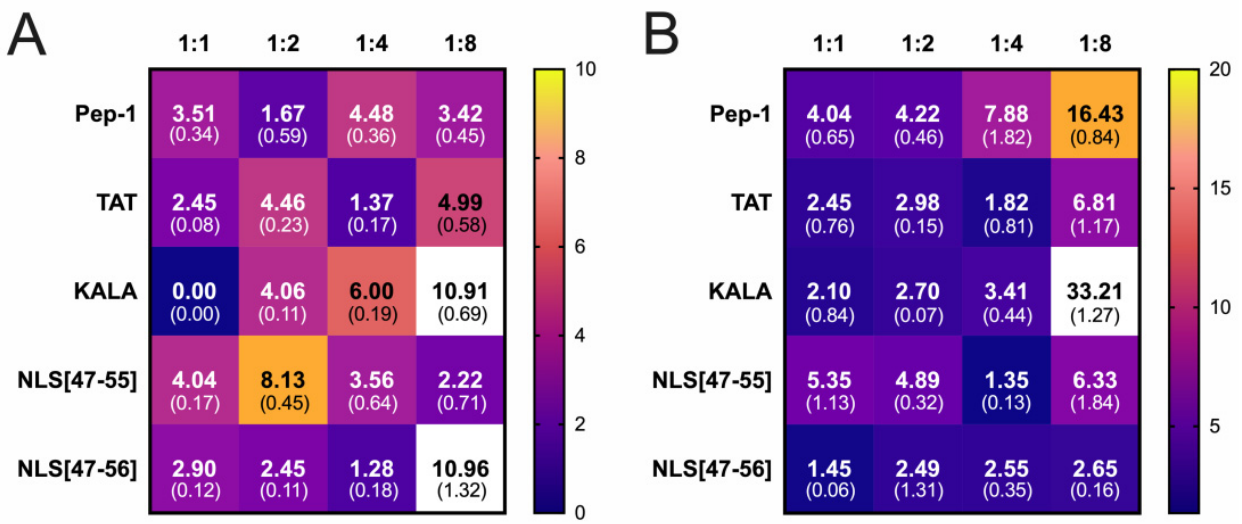

Figure 9. Effect of $24 \mathrm{~h}$ culture in the presence of complexes in CRs of 1:1, 1:2, 1:4 and 1:8. The complexes were formed using incubation of $2 \mu \mathrm{g}$ pmaxGFP with chosen CPPs at $37^{\circ} \mathrm{C}$ for $15 \mathrm{~min}$. CR, charge ratio. (A) Transfection efficiency. (B) Percent of cells with abnormal morphology. Data are presented as means, numbers in parentheses represent standard deviations. 


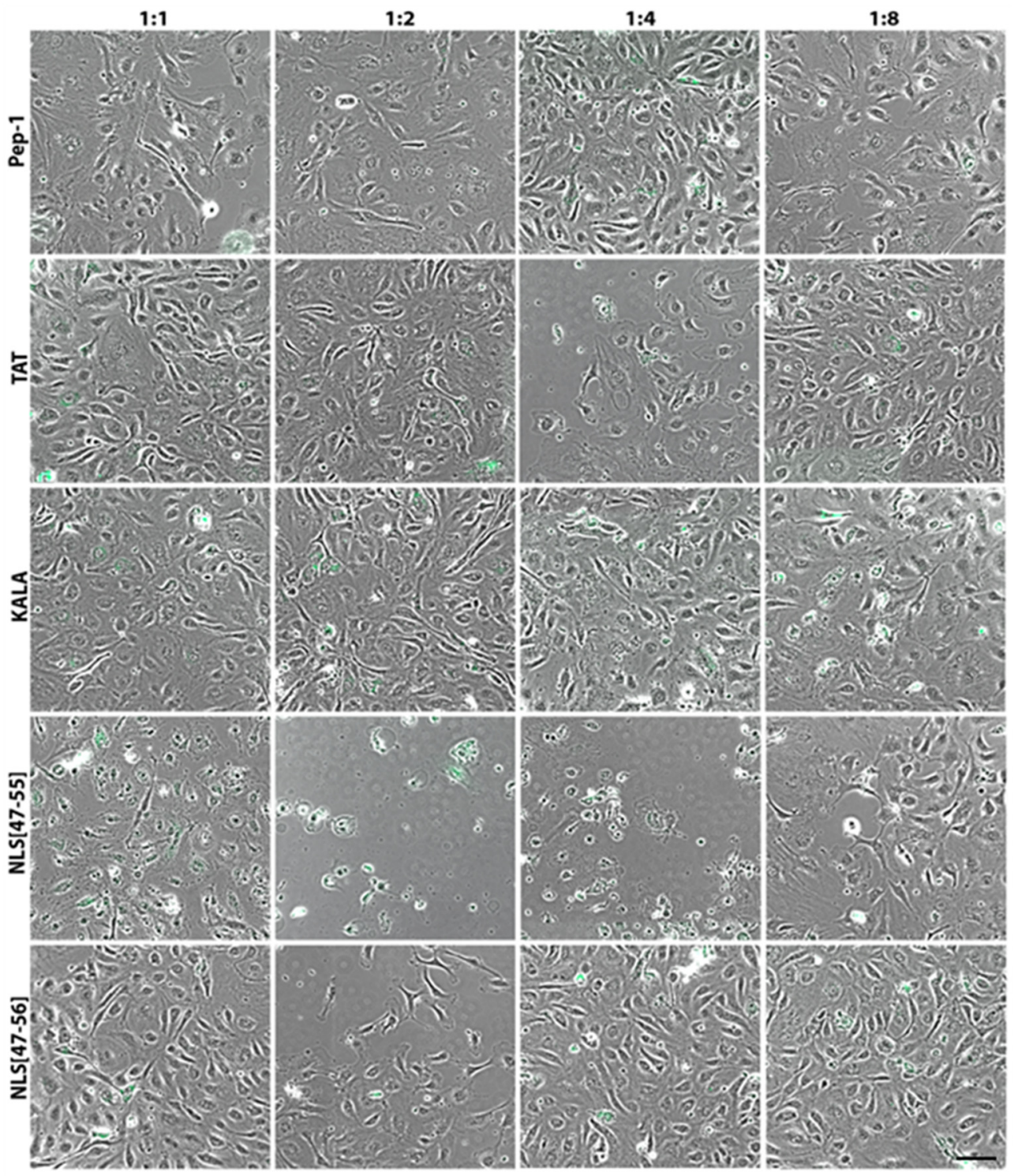

Figure 10. Results of $24 \mathrm{~h}$ culture in the presence of complexes in CRs of 1:1, 1:2, 1:4 and 1:8. The complexes were formed using incubation of $2 \mu \mathrm{g}$ pmaxGFP with chosen CPPs at $21^{\circ} \mathrm{C}$ for $30 \mathrm{~min}$. Bar $=50 \mu \mathrm{m}$. CR, charge ratio.

A

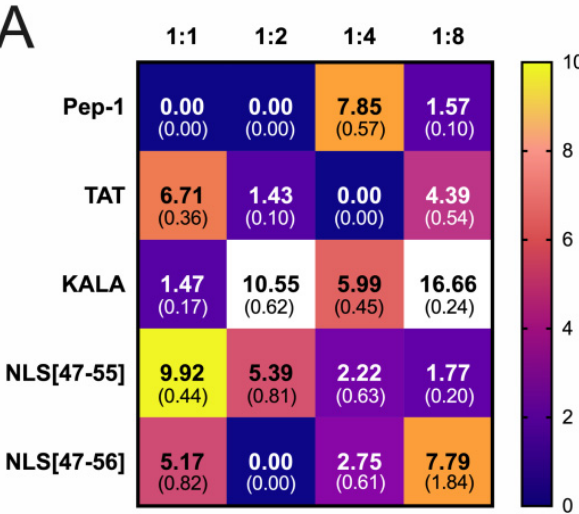

B

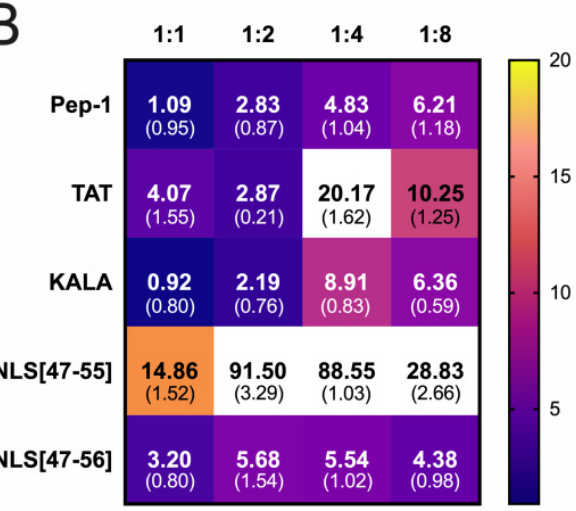

Figure 11. Effect of $24 \mathrm{~h}$ culture in the presence of complexes in CRs of 1:1, 1:2, 1:4 and 1:8. The complexes were formed using incubation of $2 \mu \mathrm{g}$ pmaxGFP with chosen CPPs at $21^{\circ} \mathrm{C}$ for $30 \mathrm{~min}$. CR, charge ratio. (A) Transfection efficiency. (B) Percent of cells with abnormal morphology. Data are presented as means, numbers in parentheses represent standard deviations. 


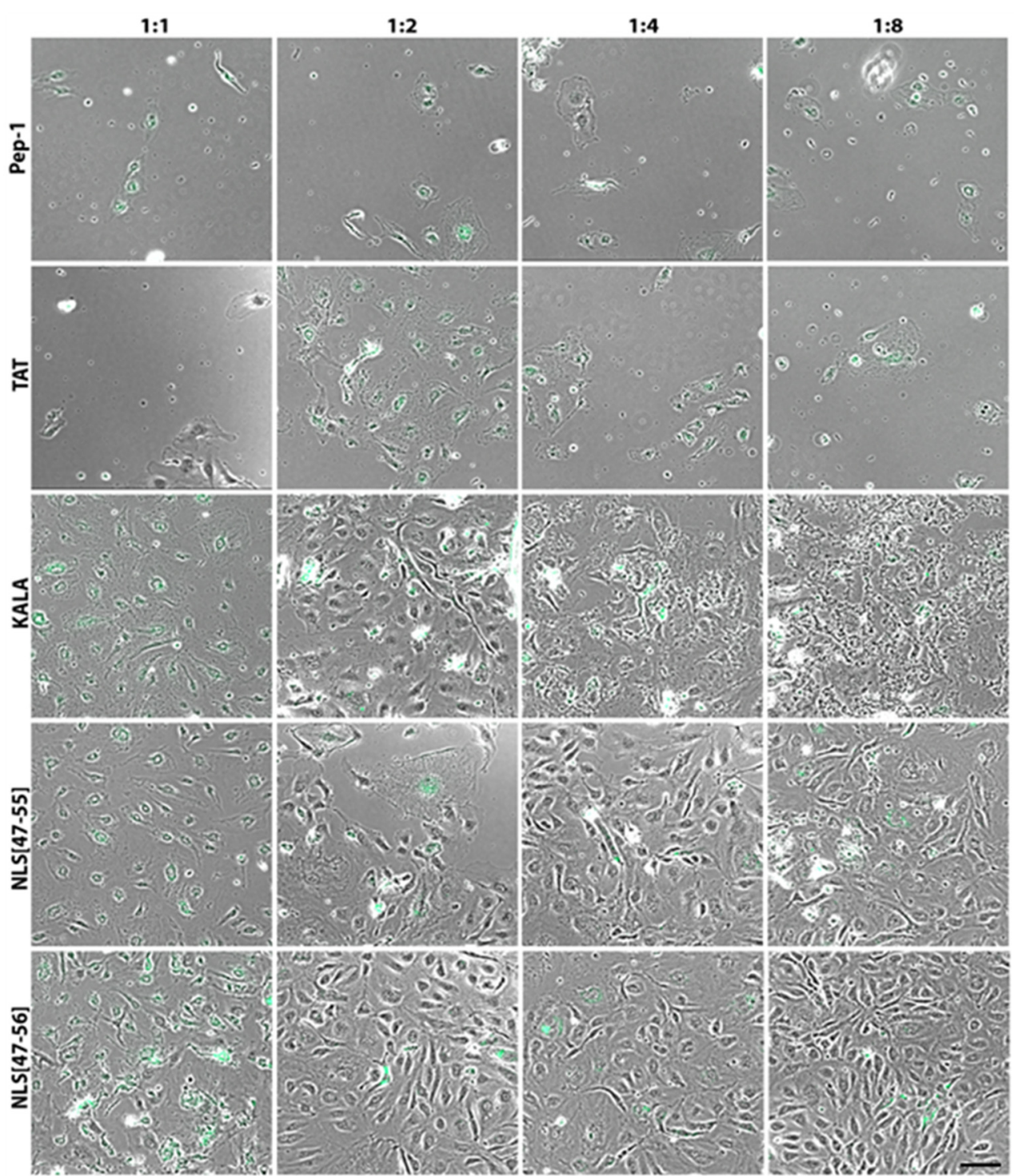

Figure 12. Results of $24 \mathrm{~h}$ culture in the presence of complexes in CRs of 1:1, 1:2, 1:4 and 1:8. The complexes were formed using incubation of $2 \mu \mathrm{g}$ pmaxGFP with chosen CPPs at $37^{\circ} \mathrm{C}$ for $30 \mathrm{~min}$. Bar $=50 \mu \mathrm{m}$. CR, charge ratio.

A

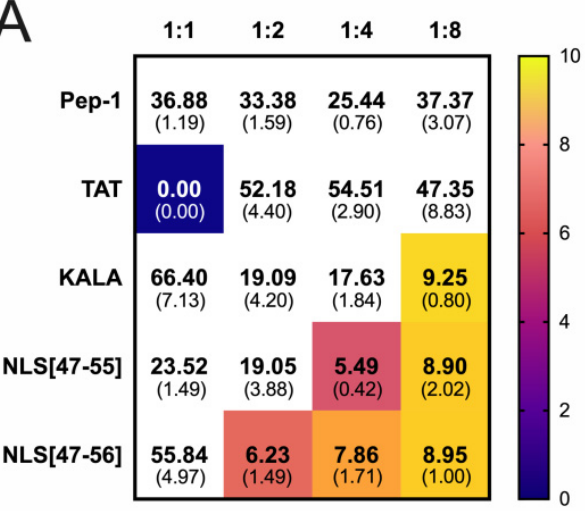

B

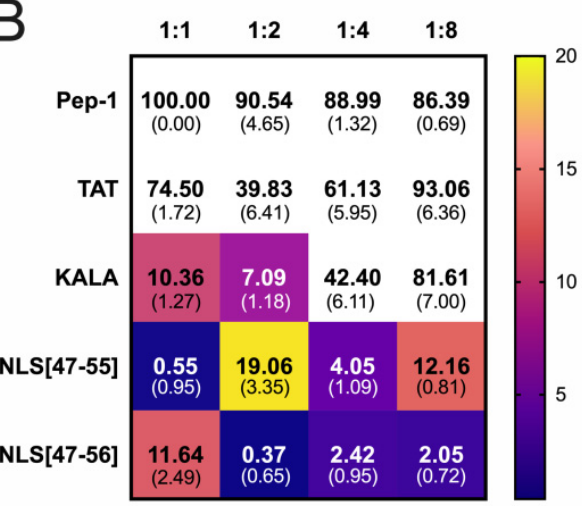

Figure 13. Results of $24 \mathrm{~h}$ culture in the presence of complexes in CRs of 1:1, 1:2, 1:4 and 1:8. The complexes were formed using incubation of $2 \mu \mathrm{g}$ pmaxGFP with chosen CPPs at $37^{\circ} \mathrm{C}$ for $30 \mathrm{~min}$. CR, charge ratio. (A) Transfection efficiency. (B) Percent of cells with abnormal morphology. Data are presented as means, numbers in parentheses represent standard deviations. 


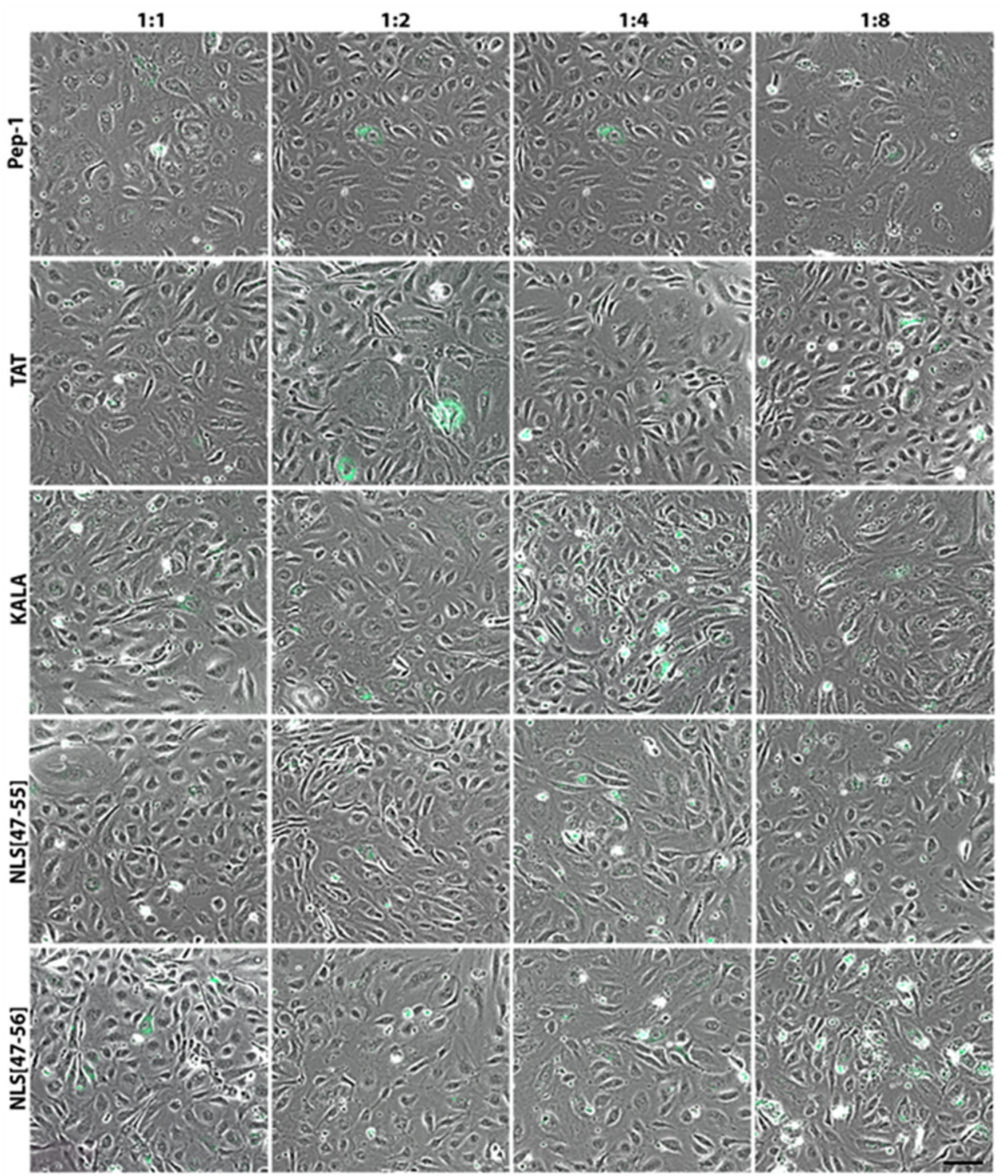

Figure 14. Results of $48 \mathrm{~h}$ culture in the presence of complexes in CRs of 1:1, 1:2, 1:4 and 1:8. The complexes were formed using incubation of $2 \mu \mathrm{g}$ pmaxGFP with chosen CPPs at $21^{\circ} \mathrm{C}$ for $15 \mathrm{~min}$. Bar $=50 \mu \mathrm{m}$. CR, charge ratio.

A

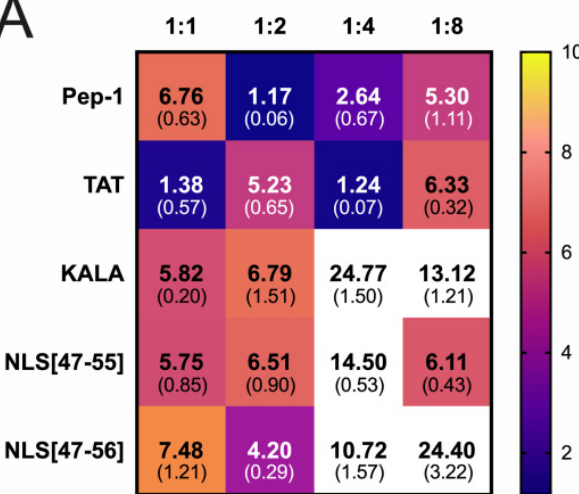

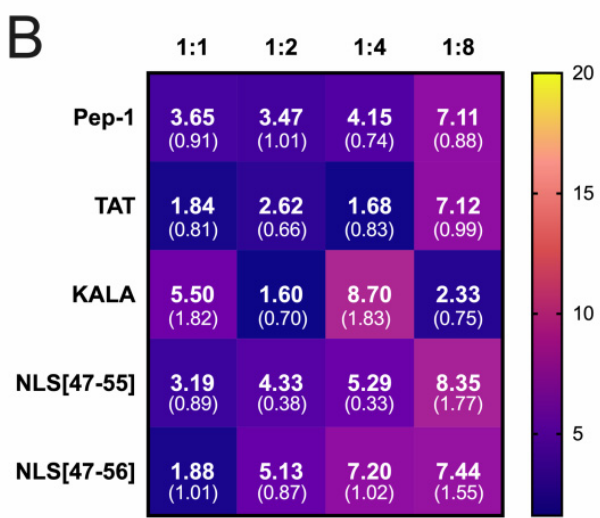

Figure 15. Effect of $48 \mathrm{~h}$ culture in the presence of complexes in CRs of 1:1, 1:2, 1:4 and 1:8. The complexes were formed using incubation of $2 \mu \mathrm{g}$ pmaxGFP with chosen CPPs at $21^{\circ} \mathrm{C}$ for $15 \mathrm{~min}$. Bar $=50 \mu \mathrm{m}$. CR, charge ratio. (A) Transfection efficiency. (B) Percent of cells with abnormal morphology. Data are presented as means, numbers in parentheses represent standard deviations. 


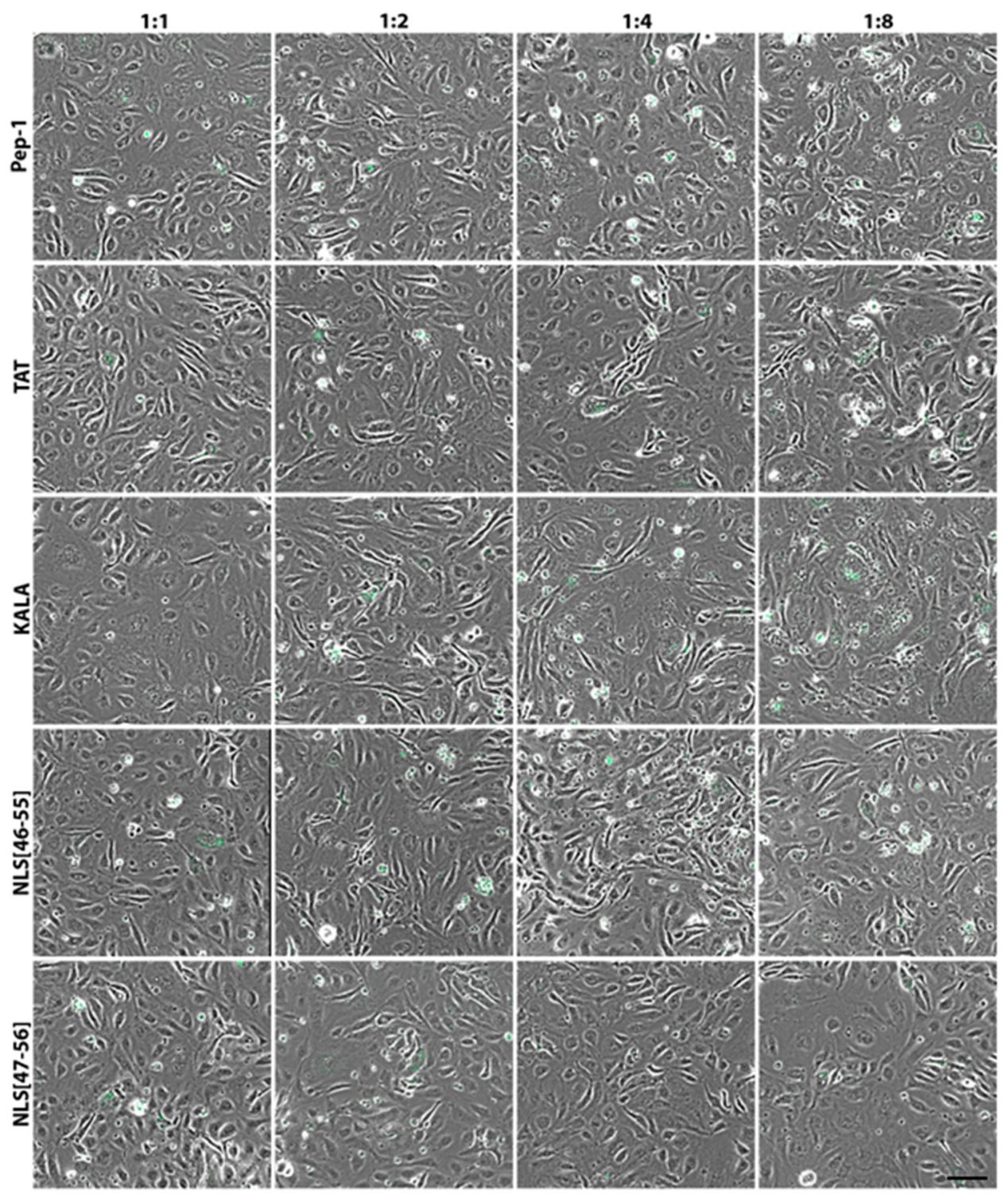

Figure 16. Results of $48 \mathrm{~h}$ culture in the presence of complexes in CRs of 1:1, 1:2, 1:4 and 1:8. The complexes were formed using incubation of $2 \mu \mathrm{g}$ pmaxGFP with chosen CPPs at $37^{\circ} \mathrm{C}$ for $15 \mathrm{~min}$. Bar $=50 \mu \mathrm{m}$. CR, charge ratio.

A

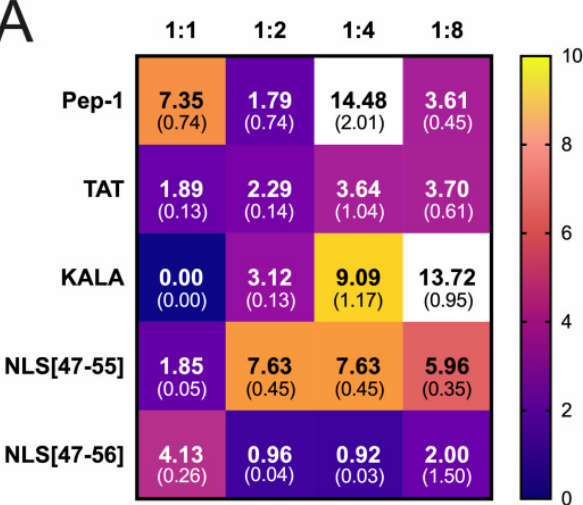

B

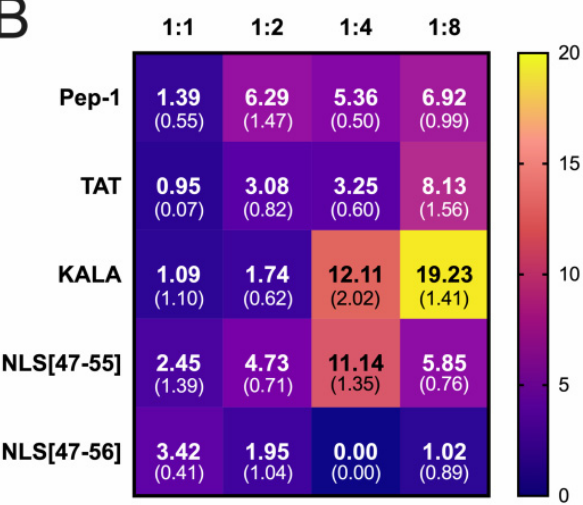

Figure 17. Effect of $48 \mathrm{~h}$ culture in the presence of complexes in CRs of 1:1, 1:2, 1:4 and 1:8. The complexes were formed using incubation of $2 \mu \mathrm{g}$ pmaxGFP with chosen CPPs at $37^{\circ} \mathrm{C}$ for $15 \mathrm{~min}$. CR, charge ratio. (A) Transfection efficiency. (B) Percent of cells with abnormal morphology. Data are presented as means, numbers in parentheses represent standard deviations. 


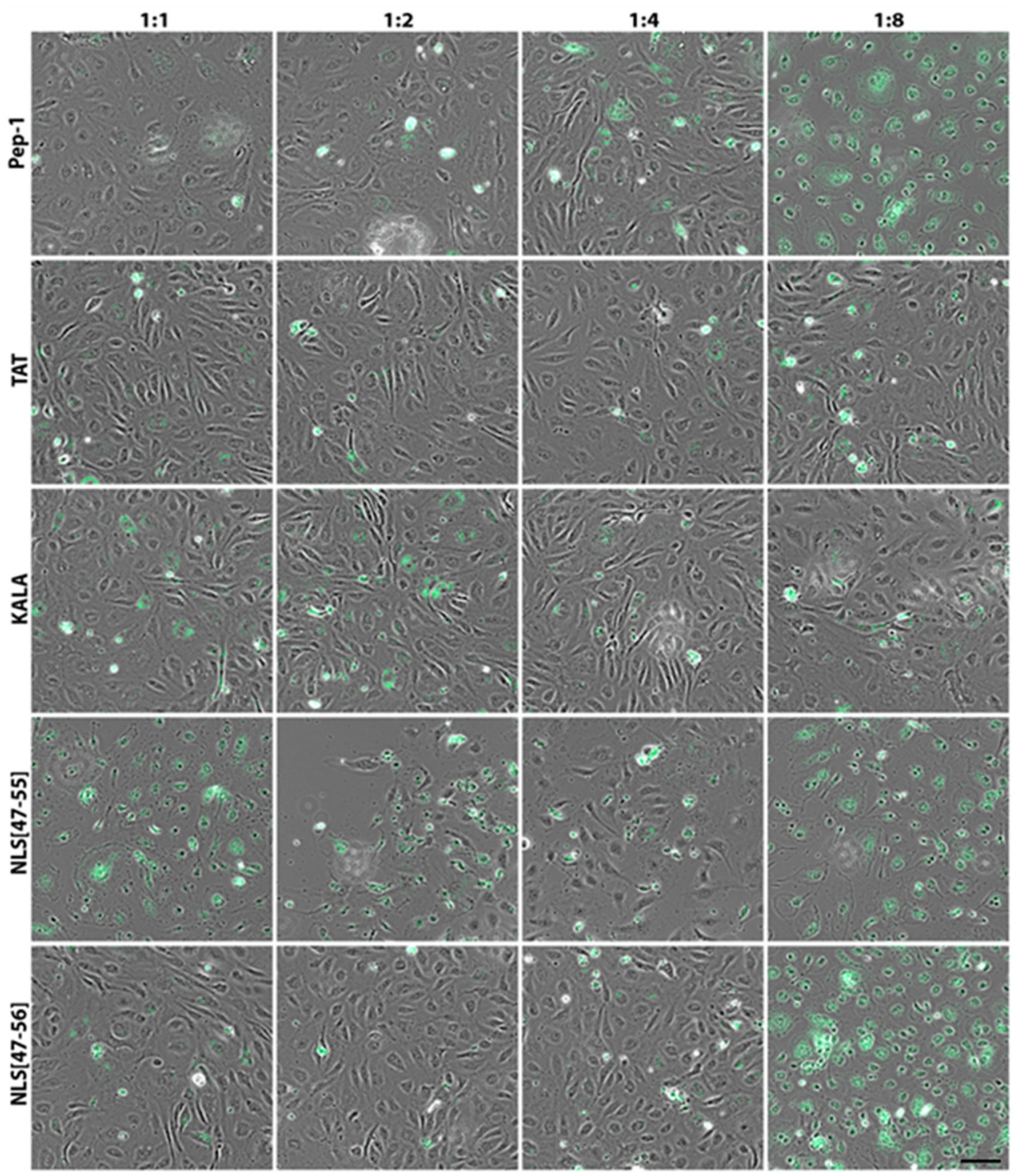

Figure 18. Results of $48 \mathrm{~h}$ culture in the presence of complexes in CRs of 1:1, 1:2, 1:4 and 1:8. The complexes were formed using incubation of $2 \mu \mathrm{g}$ pmaxGFP with chosen CPPs at $21^{\circ} \mathrm{C}$ for $30 \mathrm{~min}$. Bar $=50 \mu \mathrm{m}$. CR, charge ratio.
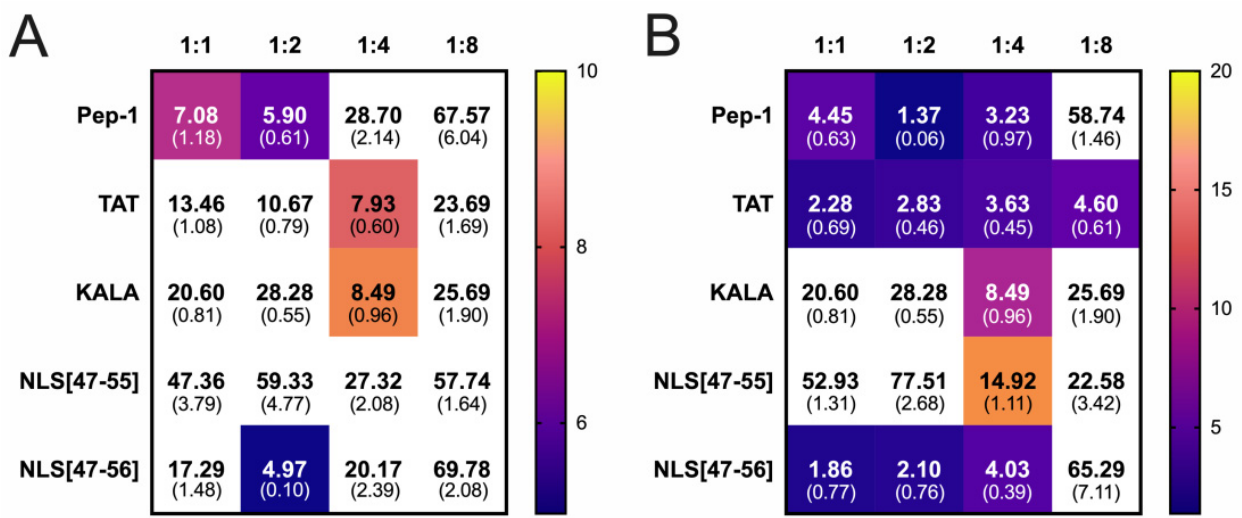

Figure 19. Effect of $48 \mathrm{~h}$ culture in the presence of complexes in CRs of 1:1, 1:2, 1:4 and 1:8. The complexes were formed using incubation of $2 \mu \mathrm{g}$ pmaxGFP with chosen CPPs at $21^{\circ} \mathrm{C}$ for $30 \mathrm{~min}$. CR, charge ratio. (A) Transfection efficiency. (B) Percent of cells with abnormal morphology. Data are presented as means, numbers in parentheses represent standard deviations. 


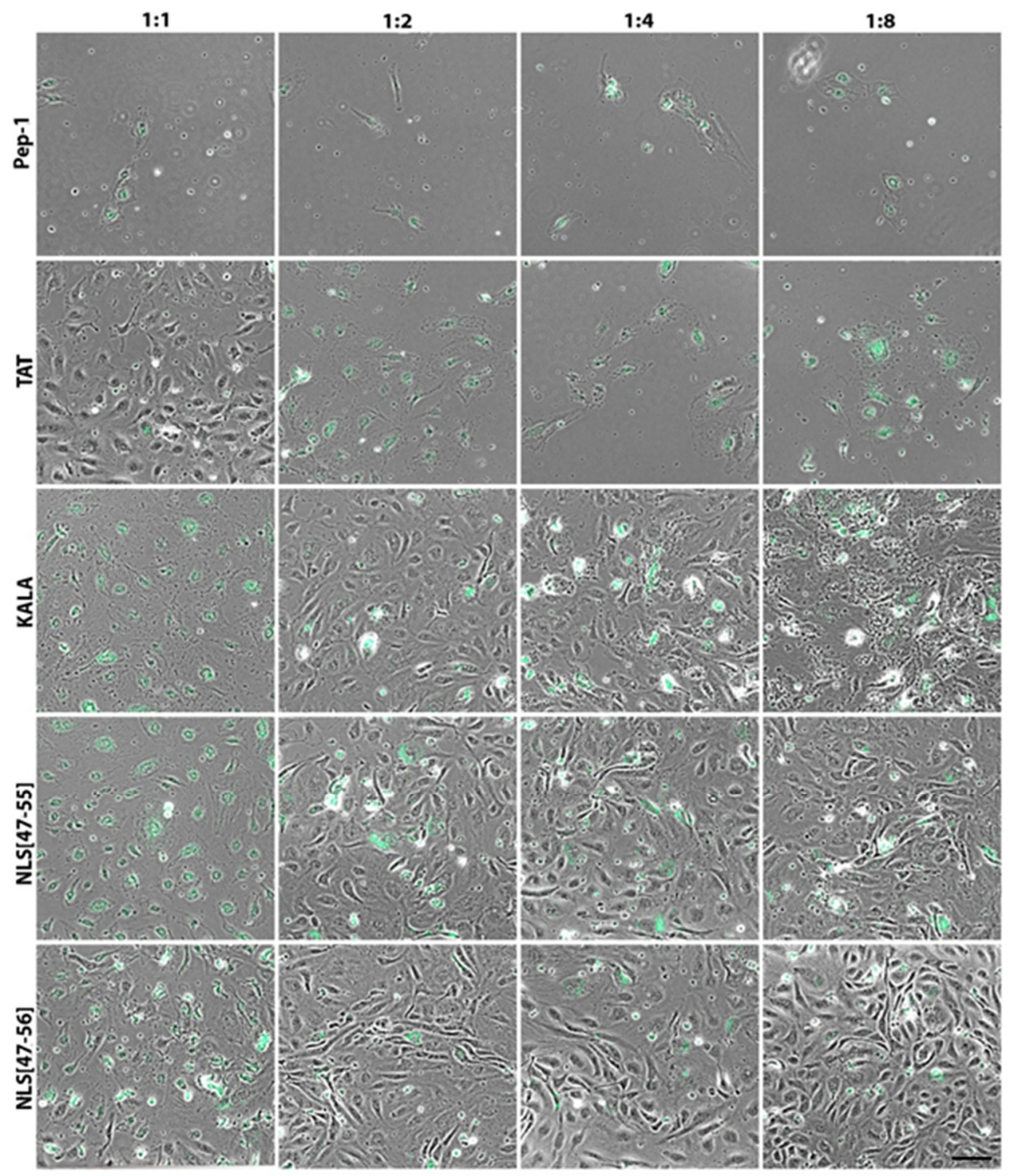

Figure 20. Results of $48 \mathrm{~h}$ culture in the presence of complexes in CRs of 1:1, 1:2, 1:4 and 1:8. The complexes were formed using incubation of $2 \mu \mathrm{g}$ pmaxGFP with chosen CPPs at $37^{\circ} \mathrm{C}$ for $30 \mathrm{~min}$. Bar $=50 \mu \mathrm{m}$. CR, charge ratio.

A

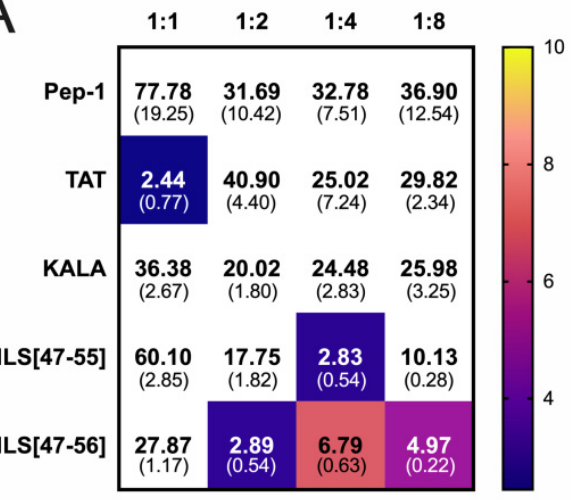

B

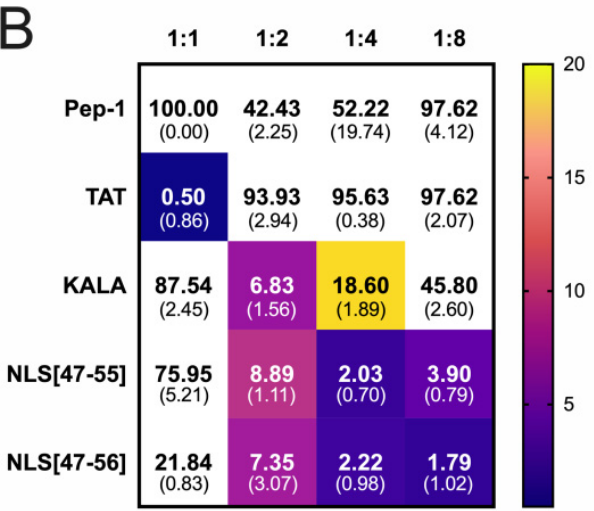

Figure 21. Effect of $48 \mathrm{~h}$ culture in the presence of complexes in CRs of 1:1, 1:2, 1:4 and 1:8. The complexes were formed using incubation of $2 \mu \mathrm{g}$ pmaxGFP with chosen CPPs at $37^{\circ} \mathrm{C}$ for $30 \mathrm{~min}$. CR, charge ratio. (A) Transfection efficiency. (B) Percent of cells with abnormal morphology. Data are presented as means, numbers in parentheses represent standard deviations. 


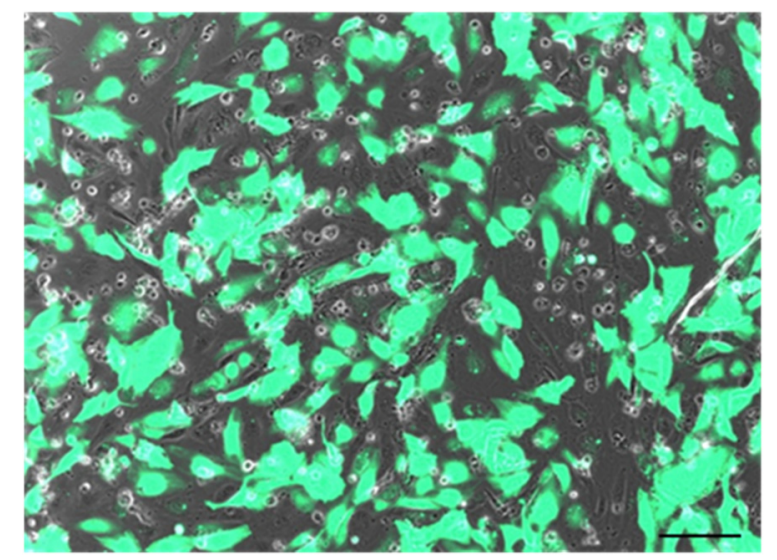

Figure 22. Results of pHCAECs' transfection by nucleofection. Bar $=50 \mu \mathrm{m}$.

\section{Discussion}

Drugs containing proteins or nucleic acids are a promising form of therapy for many diseases, including those considered incurable at the current level of medicine development. The structure of the cell membrane, however, does not allow direct cell penetration. The crucial issue is the choice of the appropriate method of transport to the cells' interior. The viral and non-viral systems created so far have many significant disadvantages. Therefore, attempts are still underway to optimize the transport of macromolecules across the cell membrane. The results published so far indicate that chimeric molecules composed of CPPs and various molecules can internalize cells both in vitro and in vivo [6,7]. Insufficient understanding of the internalization mechanism is holding back their commercialization. However, some of the best-known penetrating peptides have been included in clinical trials with moderate success $[8,9]$. Nevertheless, studies regarding the effectiveness of the production conditions of chimeric particles composed of CPPs and selected therapeutic molecules on the cytotoxicity and process efficiency are still necessary. This will allow for improvement of the methodology to maximize benefits.

Endothelium obtained from a $70 \mathrm{~kg}$ male body would weigh over $1 \mathrm{~kg}$, cover an area of almost $3 \mathrm{~m}^{2}$, and contain about a trillion cells. These specialized cells build a layer that is the first barrier between blood components and other body tissues. For this reason, the endothelium is constantly exposed to harmful substances transported within liquid tissues. At the same time, maintaining the proper functioning of the endothelium is pivotal for the organisms [10]. Endothelial cells participate in such important processes as blood pressure regulation, coagulation, fibrinolysis, angiogenesis, and inflammatory reactions. Abnormalities in the functioning of endothelial cells are the cause of many diseases, e.g., atherosclerosis and hypertension. These disorders are also associated with stroke, venous thrombosis, peripheral vascular disease, chronic renal failure, cancer development, and vascular complications in diabetes [10]. Methods of proven efficacy in maintaining normal endothelial function include a Mediterranean diet, weight reduction, stopping smoking, or exercise [11]. Unfortunately, changes that have already appeared cannot be removed by such simple methods. In addition to many conventional approaches, such as invasive and non-invasive procedures and pharmacotherapy, the use of peptides penetrating cells to introduce molecules that restore or support endothelial function is a promising field of research.

Effective internalization of CPPs in combination with various cargo has also been confirmed for endothelial cells. The first report on this subject came from 2000 when penetrine was used to transfer the caveolin-1 scaffold domain to mouse endothelial cells [7]. The study aimed to determine the role of this domain in the regulation of signal transduction. The result was an effective uptake of the constructed chimeric protein, which was manifested in the inhibition of NO production and a reduction in the degree of acetylcholine-induced vasodilation. Furthermore, peptide administration was associated with the inhibition of 
acute inflammation and vascular leakage to a similar extent as the use of glucocorticoids such as dexamethasone or endothelial NO synthase inhibitor. Penetrin was attached to the molecule via covalent binding and administered intraperitoneally to mice at 0.3 and $1 \mathrm{mg} / \mathrm{kg}$ three times for $24 \mathrm{~h}$. The administration did not significantly affect animal body functions, such as blood pressure or heart rate [7].

The ability of cell-penetrating peptides to internalize endothelial cells has also been used to determine the role of cyclic guanosine monophosphate (cGMP) cGMP protein kinase (cGPK) in nitric oxide-dependent vasodilatation and blood pressure regulation [12]. For this purpose, a chimeric protein containing a cGPK inhibitor peptide in combination with TAT was synthesized. In addition, in this case, a covalent bond was used. The chimeric protein was administered to 8 mice by continuous 72-h infusion into the internal jugular vein. Effective internalization of peptides associated with cGPK inhibitors was confirmed by the measurements of systolic and diastolic blood pressure, which values increased in the study group. The presence of inhibitors in cardiac tissues has also been confirmed by Western blotting. Changes in blood pressure were not observed in any of the control groups. The researchers did not mention any side effects of CPPs, and the administration of unbound TAT molecules did not have any effect on blood pressure [12]. In turn, Pep-1 was used to introduce the chimeric Pep-1-EGFP protein into HUVECs (human umbilical vein endothelial cells) [13]. For this purpose, two expression plasmids, pET15b-EGFP (expressing only EGFP) and pET15b-PEP-1-EGFP (expressing both EGFP and Pep-1 bound covalently), were introduced into E.coli cells. The fusion protein and EGFP were isolated by affinity chromatography. Purified EGFP protein was not transduced into HUVEC cells. In turn, the Pep-1-EGFP fusion protein internalized into the cells in a time and dose-dependent manner. EGFP fluorescence was observed after $27 \mathrm{~h}$. Additionally, the fusion peptide did not show a cytotoxic effect in the MTT test, even at the highest dose of $200 \mu \mathrm{mol} / \mathrm{L}$ [13].

So far, no clinical trials have been carried out using CPPs to transport molecules to vascular endothelium in humans. However, they were used to introduce an anti-c-Myc antisense molecule called AVI-5126 into vascular smooth muscle cells. Researchers wanted to determine whether graft immersed in a solution containing AVI-5126 in combination with CPP rich in arginine before bypass surgery would reduce the degree of inner layer growth and thus the risk of vascular occlusion at the intervention site (NCT00451256) [14]. Unfortunately, the studies were suspended in phase II due to insufficient efficacy [15]. A better approach could be the acceleration of endothelialization in the intervention site instead of inhibiting neointima growth. Perhaps the opportunity for this will also be the use of CPPs. With proven effective internalization of vascular endothelial cells in in vivo studies, it is probably only a matter of time before they are used in clinical trials.

Although the method of creating covalent bonds between a penetrating and transported molecule is still the most widespread, the formation of non-covalent interactions arouses more and more interest. Studies have confirmed that simple incubation of CPPs with selected molecules in the appropriate CR leads to bonding. Literature reports have confirmed the ability of TAT [16], Pep-1 [13], and KALA [17] to form non-covalent bonds. Moreover, each of the selected peptides contains sequences of a cationic character capable of producing electrostatic interactions with negatively charged phosphate residues in plasmid DNA. The binding efficiency strongly depends on the ratio of these charges. By default, low $C R$ values between 1:1 and 1:10 are used. However, in some cases, the CR with optimal efficiency can be as high as 1:100 [18]. Selected penetrating peptides in CR 1:16 led to severe damage to endothelial cells, which justifies the subsequent reduction of the ratio used to a maximum value of 1:8. However, the most effective $C R$ differed depending on the type of CPP used.

The efficiency of generating non-covalent interactions between CPPs and selected molecules depends not only on CR but also on the conditions of the complex formation. The study used two variable incubation parameters for selected CPPs and pDNA: time and temperature. Both of the times (15 and $30 \mathrm{~min}$ ) applied in the study are commonly used in laboratory practice $[3,12,13]$. However, for pmaxGFP, the extension of the incubation 
time from 15 to $30 \mathrm{~min}$ led to an increase in the number of GFP positive cells. This suggests that more time is necessary to create non-covalent interactions between the protein and the plasmid. There was no significant effect of prolonged incubation on changes in cell morphology. In turn, an increase in the incubation temperature of CPPs with pmaxGFP intensified the cytotoxic effect, especially for Pep-1 and TAT. This could be due to inefficient binding of plasmid DNA by CPPs under these conditions. Research has shown that free CPPs are characterized by higher cytotoxicity than those associated with the transported molecule [19]. It also confirms the observed decrease in the number of GFP-positive cells when the incubation temperature increased. Based on the obtained data, it can be concluded that room temperature is optimal to create non-covalent interactions between selected CPPs and pmaxGFP. This is consistent with the previously obtained results [20]. High temperature may also be a factor that slightly changes protein activity. Optimization of the binding process should therefore be based on increasing the incubation time of CPPs with the transported molecule rather than increasing the temperature. The complexes were formed in an aqueous environment, which is also one of the standard methods. However, different approaches may be used since the complexes may be formed in various buffers [21] or culture media [22]. According to the current state of knowledge, the efficiency of using these environments has not been compared so far. However, due to the formation of electrostatic interactions, the presence of ions and other particles in the environment may be crucial. The amount of plasmid used was also important. Incubation of $1 \mu \mathrm{g}$ of the plasmid with CPPs showed only single cells characterized by GFP expression. A better effect was obtained for $2 \mu \mathrm{g}$ of the plasmid. Therefore, only this amount was used in the later stages of the experiment. Literature data confirm the satisfactory transduction level of $1 \mu \mathrm{g}$ plasmid conditioning GFP expression combined with TAT [22]. However, the optimal amount due to the use of transcriptional machinery of the host cell may closely depend on the type of cell line used. The incubation time of the pHCAEC with selected peptides was also assessed. The effectiveness of the process was tested after 24 or $48 \mathrm{~h}$ of culture in a medium containing CPPs. Prolonged incubation intensified the effect. Research confirms the effective internalization of protein molecules introduced with CPPs within 5 min. However, for nucleic acids, the maximum efficiency is observed much later [13]. This time is necessary not only for the internalization but also for the expression of the introduced gene. However, shorter incubation times are also used. In the case of CRISPR/Cas9 system elements introduced into HEK293T (human embryonic kidney cells), HeLa, embryonic stem cells, and embryonic tumor cells using synthetic peptide cells were cultured in the presence of complexes only for $4 \mathrm{~h}$. Cell observation was carried out after another $24 \mathrm{~h}$ of culture in pure medium and confirmed effective internalization [23]. Reduction of the exposure time of cells could potentially limit cytotoxicity. However, most studies do not confirm the negative effect of low CPP concentrations on cells in the case of either 24 or $48 \mathrm{~h}$ culture.

Penetrating peptides are generally considered safe to use. Most studies have not demonstrated any cytotoxicity or immunogenicity. The results obtained in the presented study show an increase in cytotoxic effect with an increased CR value and incubation temperature. For KALA, changes in the cell morphology can already be observed at CR 1:8, whereas CR 1:16 caused a significant toxic effect. This is in line with the literature reports. Wan et al. confirmed the minimal cytotoxicity of KALA in CR as between 1:1 and 1:10 and demonstrated its significant toxic effect at higher ratios [24]. In the case of the two other peptides, even in the highest CR used, no significant morphological changes were observed when the incubation of CPPs with the plasmid took place at room temperature (RT). However, increasing the temperature during complex formation led to a cytotoxic effect at a CR of only 1:2. Due to the characteristics of pHCAECs, we were unable to directly indicate the cytotoxicity of CPPs or CPPs-plasmid complexes using the MTT assay. We observed huge discrepancies in the MTT results (data not shown) and morphology of cells, which may be connected with their high sensitivity to changes in cell to extracellular matrix adhesion. 
Another problem is the way CPPs internalize the cell. The two main mechanisms of cell membrane penetration are direct translocation and endocytosis. Endocytosis is limited as the entrapment of CPPs in the endocytic follicle leads to their degradation. However, in some cases, methods aimed to intensify the phenomenon of molecules escaping from early endocytic vesicles before lysis have been used. Studies have shown that the primary mechanism for the transduction of the cell membrane by Pep-1 is direct translocation [25]. KALA enters the cell mainly through endocytosis. However, it can escape from the early endocytic vesicles [24]. In turn, the model of cell membrane penetration by TAT probably changes with temperature. Direct translocation occurs at lower temperatures, while endocytosis becomes the main penetration mechanism at higher temperatures [26].

The disadvantage of non-covalent binding of CPPs remains the impact of many factors on process efficiency. These factors are: (I) the type of cell line, (II) the type of transported molecule and its concentration, (III) the properties of the penetrating peptide, (IV) the temperature and incubation time, (V) the CR used, and (VI) the length of the culture period with complexes. Another variable that may influence the efficiency of CPP-cargo complex formation is the $\mathrm{pH}$ of incubation. As the study already involved a large number of variables, adding another one would make it extremely complicated, and thus, it was not considered. Applying many variables complicates the optimization process since optimization involves many variants. It extends the time of experiments and significantly increases their costs. It also makes it impossible to specify a universal protocol for the use of CPPs. Despite these adversities, there are many reports regarding effective cell penetration by CPPs in non-covalent interactions with other molecules like siRNA [20], proteins [27], and plasmids [28]. So far, however, no similar tests have been performed on endothelial cells.

Unfortunately, the introduction of pmaxGFP expression plasmids in non-covalent combinations with CPPs into pHCAEC cells did not bring satisfactory results. Despite the varied conditions of complex formation and prolonged time of culture or the use of different CPPs, efficiency similar to the results obtained with electroporation was not achieved. This may be due to the characteristics of endothelial cells. Tight intercellular connections may not allow the internalization of weak CPPs and plasmid complexes. According to our current state of knowledge, this is the only study on the introduction of CPPs in non-covalent junctions into endothelial cells. The solution, in this case, is probably the use of covalent bonds. However, this prevents the transport of plasmids as they do not contain free ends capable of forming a connection.

Additionally, two NLS sequences were used to compare transduction efficiency. NLS is a group of short cationic peptides containing a polylysine, polyarginine, or polyproline fragment that allows the molecule to be transported to the cell nucleus through nuclear pores. Some NLSs can also penetrate the cell membrane [29]. Studies by Koo et al. showed that the interleukin $1 \alpha$ precursor ( $\mathrm{pIL}-1 \alpha$ ) can internalize the cell with similar efficiency as TAT [29]. Moreover, effective cell penetration in vivo has also been demonstrated in rat organisms and organs such as the liver, spleen, and intestines. In our study, the observations showed that NLS works with greater efficiency than the other CPPs used. Both NLSs showed optimal performance when complexes were formed for $30 \mathrm{~min}$ at $21^{\circ} \mathrm{C}$, followed by $48 \mathrm{~h}$ incubation with the cells. The most effective CR for NLS [47-55] was 1:1, while for NLS [47-56] it reached 1:8. However, the results were still not as satisfying as those obtained for electroporation.

\section{Conclusions}

Therapeutic methods based on proteins or nucleic acids require developing new, safer tools for their introduction. In this context, the use of cell-penetrating peptides seems particularly attractive. The simplest way to form connections between CPPs and cargo molecules is the introduction of non-covalent interactions. However, in some cases, like tightly packed endothelial cells, this approach may be less effective. Appropriate manipulation of complex formation and incubation conditions may influence the obtained 
results. Undoubtedly, there is a need for more extensive research that will allow us to determine the most effective protocols, especially in the case of cells as difficult to culture as endothelial cells.

Author Contributions: Conceptualization, M.G. and A.G.; Methodology, W.Z. and M.G.; Software, W.Z. and M.G.; Validation, M.G. and A.G.; Formal Analysis, W.Z. and M.G.; Investigation, W.Z., K.M. and M.H.-W.; Resources, M.G.; Data Curation, W.Z., M.G., K.M.; Writing-Original Draft Preparation, W.Z.; Writing-Review \& Editing, M.G. and A.G.; Visualization, W.Z. and M.G.; Supervision, A.G.; Project Administration, M.G.; Funding Acquisition, M.G. All authors have read and agreed to the published version of the manuscript.

Funding: This study was supported by grant no. 2015/17/D/NZ7/00809 to MG from National Science Centre, Poland.

Institutional Review Board Statement: Not applicable.

Informed Consent Statement: Not applicable.

Data Availability Statement: The datasets generated for this study are available on request to the corresponding author.

Acknowledgments: We would like to thank members of the Department of Histology and Embryology CM UMK for technical assistance and helpful discussions.

Conflicts of Interest: The authors report no conflicts of interest.

\section{References}

1. Gagat, M.; Zielińska, W.; Grzanka, A. Cell-penetrating peptides and their utility in genome function modifications (Review). Int. J. Mol. Med. 2017, 40, 1615-1623. [CrossRef]

2. Meade, B.R.; Dowdy, S.F. Exogenous siRNA delivery using peptide transduction domains/cell penetrating peptides. Adv. Drug Deliv. Rev. 2007, 59, 134-140. [CrossRef] [PubMed]

3. Wang, Z.; Chen, Y.; Liu, E.; Gong, J.; Shin, M.C.; Huang, Y. CPP-mediated protein delivery in a noncovalent form: Proof-of-concept for percutaneous and intranasal delivery. Protein Pept. Lett. 2014, 21, 1129-1136. [CrossRef] [PubMed]

4. Iwase, Y.; Kamei, N.; Khafagy, E.S.; Miyamoto, M.; Takeda-Morishita, M. Use of a non-covalent cell-penetrating peptide strategy to enhance the nasal delivery of interferon beta and its PEGylated form. Int. J. Pharm. 2016, 510, 304-310. [CrossRef] [PubMed]

5. Pärnaste, L.; Arukuusk, P.; Langel, K.; Tenson, T.; Langel, Ü. The Formation of Nanoparticles between Small Interfering RNA and Amphipathic Cell-Penetrating Peptides. Mol. Ther. Nucleic Acids 2017, 7, 1-10. [CrossRef]

6. Liu, J.; Afshar, S. In Vitro Assays: Friends or Foes of Cell-Penetrating Peptides. Int. J. Mol. Sci. 2020, 21, 4719. [CrossRef]

7. Bucci, M.; Gratton, J.P.; Rudic, R.D.; Acevedo, L.; Roviezzo, F.; Cirino, G.; Sessa, W.C. In vivo delivery of the caveolin-1 scaffolding domain inhibits nitric oxide synthesis and reduces inflammation. Nat. Med. 2000, 6, 1362-1367. [CrossRef] [PubMed]

8. US National Library of Medicine. ClinicalTrials.gov. 2019. Available online: https:/ / clinicaltrials.gov/ct2/show / NCT00914914 (accessed on 12 January 2021).

9. Tripathi, P.P.; Arami, H.; Banga, I.; Gupta, J.; Gandhi, S. Cell penetrating peptides in preclinical and clinical cancer diagnosis and therapy. Oncotarget 2018, 9, 37252-37267. [CrossRef]

10. Incalza, M.A.; D'Oria, R.; Natalicchio, A.; Perrini, S.; Laviola, L.; Giorgino, F. Oxidative stress and reactive oxygen species in endothelial dysfunction associated with cardiovascular and metabolic diseases. Vascul. Pharmacol. 2018, 100, 1-19. [CrossRef]

11. Widmer, R.J.; Allison, T.G.; Keane, B.; Dallas, A.; Bailey, K.R.; Lerman, L.O.; Lerman, A. Workplace Digital Health Is Associated with Improved Cardiovascular Risk Factors in a Frequency-Dependent Fashion: A Large Prospective Observational Cohort Study. PLoS ONE 2016, 11, e0152657. [CrossRef]

12. Poh, K.K.; Lu, P.; Qin, G.; Silver, M.; Losordo, D.W.; Mendelsohn, M.E.; Zhu, Y. Endothelial dysfunction and systemic hypertension by selective cGMP-dependent protein kinase I inhibition using novel cell-penetrating peptide delivered in vivo. Int. J. Cardiol. 2013, 167, 2114-2119. [CrossRef] [PubMed]

13. Dong, X.; Wang, J.N.; Huang, Y.Z.; Guo, L.Y. Expression and purification of PEP-1-EGFP fusion protein and its transduction into human umbilical vein endothelial cells. Nan Fang Yi Ke Da Xue Xue Bao 2006, 26, 1114-1117. [PubMed]

14. US National Library of Medicine. ClinicalTrials.gov. 2019. Available online: https://www.clinicaltrials.gov/ct2/show/NCT004 51256 (accessed on 12 January 2021).

15. Guidotti, G.; Brambilla, L.; Rossi, D. Cell-Penetrating Peptides: From Basic Research to Clinics. Trends Pharmacol. Sci. 2017, 38, 406-424. [CrossRef] [PubMed]

16. Liu, L.; Yan, Y.; Ni, D.; Wu, S.; Chen, Y.; Chen, X.; Xiong, X.; Liu, G. TAT-functionalized PEI-grafting rice bran polysaccharides for safe and efficient gene delivery. Int. J. Biol. Macromol. 2020, 146, 1076-1086. [CrossRef] [PubMed] 
17. Miura, N.; Shaheen, S.M.; Akita, H.; Nakamura, T.; Harashima, H. A KALA-modified lipid nanoparticle containing CpG-free plasmid DNA as a potential DNA vaccine carrier for antigen presentation and as an immune-stimulative adjuvant. Nucleic Acids Res. 2015, 43, 1317-1331. [CrossRef] [PubMed]

18. Keller, A.A.; Mussbach, F.; Breitling, R.; Hemmerich, P.; Schaefer, B.; Lorkowski, S.; Reissmann, S. Relationships between Cargo, Cell Penetrating Peptides and Cell Type for Uptake of Non-Covalent Complexes into Live Cells. Pharmaceuticals 2013, 6, 184-203. [CrossRef]

19. Gros, E.; Deshayes, S.; Morris, M.C.; Aldrian-Herrada, G.; Depollier, J.; Heitz, F.; Divita, G. A non-covalent peptide-based strategy for protein and peptide nucleic acid transduction. Biochim. Biophys. Acta 2006, 1758, 384-393. [CrossRef] [PubMed]

20. Mo, R.H.; Zaro, J.L.; Shen, W.C. Comparison of cationic and amphipathic cell penetrating peptides for siRNA delivery and efficacy. Mol. Pharm. 2012, 9, 299-309. [CrossRef]

21. Morris, M.C.; Vidal, P.; Chaloin, L.; Heitz, F.; Divita, G. A new peptide vector for efficient delivery of oligonucleotides into mammalian cells. Nucleic Acids Res. 1997, 25, 2730-2736. [CrossRef] [PubMed]

22. Rudolph, C.; Plank, C.; Lausier, J.; Schillinger, U.; Müller, R.H.; Rosenecker, J. Oligomers of the arginine-rich motif of the HIV-1 TAT protein are capable of transferring plasmid DNA into cells. J. Biol. Chem. 2003, 278, 11411-11418. [CrossRef]

23. Ramakrishna, S.; Kwaku Dad, A.B.; Beloor, J.; Gopalappa, R.; Lee, S.K.; Kim, H. Gene disruption by cell-penetrating peptidemediated delivery of Cas9 protein and guide RNA. Genome Res. 2014, 24, 1020-1027. [CrossRef]

24. Wan, Y.; Moyle, P.M.; Christie, M.P.; Toth, I. Nanosized, peptide-based multicomponent DNA delivery systems: Optimization of endosome escape activity. Nanomedicine 2016, 11, 907-919. [CrossRef] [PubMed]

25. Li, X.; Huang, J.; Holden, M.A.; Chen, M. Peptide-Mediated Membrane Transport of Macromolecular Cargo Driven by Membrane Asymmetry. Anal. Chem. 2017, 89, 12369-12374. [CrossRef] [PubMed]

26. Ben-Dov, N.; Korenstein, R. The uptake of HIV Tat peptide proceeds via two pathways which differ from macropinocytosis. Biochim. Biophys. Acta 2015, 1848, 869-877. [CrossRef] [PubMed]

27. Kurzawa, L.; Pellerano, M.; Morris, M.C. PEP and CADY-mediated delivery of fluorescent peptides and proteins into living cells. Biochim. Biophys. Acta 2010, 1798, 2274-2285. [CrossRef]

28. Upadhya, A.; Sangave, P.C. Hydrophobic and electrostatic interactions between cell penetrating peptides and plasmid DNA are important for stable non-covalent complexation and intracellular delivery. J. Pept. Sci. 2016, 22, 647-659. [CrossRef]

29. Koo, J.H.; Yoon, H.; Kim, W.J.; Lim, S.; Park, H.J.; Choi, J.M. Cell membrane penetrating function of the nuclear localization sequence in human cytokine IL-1 $\alpha$. Mol. Biol. Rep. 2014, 41, 8117-8126. [CrossRef] [PubMed] 